\title{
Antifungal Activity of Pomegranate and Oak Galls Extracts Against Penicillium spp. and Aspergillus niger
}

\author{
Abdul-ghany O. Sarmamy Musa I. Taha Abdulilah S. Ismaeil \\ Department of Biology \\ College of Science \\ Salahaddin University \\ Erbil, Iraq. \\ abdulghani_umer@yahoo.com \\ Musa_gardy1963@yahoo.com \\ abdulillah1@yahoo.com
}

(Received 18/10/2010; Accepted 12/2/2011)

\begin{abstract}
Different factorial experiments were conducted during 2008-2009 in the laboratories of Biology Department, College of Science, University of Salahaddin-Erbil, to determine the effects of aqueous and ethanol extracts of pomegranate (Punica granatum L.) and oak gall (Quercus infectoria L.) at $0,5,10,15$ and $20 \%$ of raw extracts to control Penicillium spp. and Aspergillus niger after 48, 96 and 168 hours of incubation, using completely randomized design (CRD) with four replications. The results revealed that all the plant extract concentrations used were effective against the two fungi. Ethanol extracts were more efficient against the growth of mycelia of the two fungi than aqueous extracts. Penicillium spp. was more sensitive to the plant extracts of pomegranate and oak gall more than Aspergillus niger. There were significant interactions between time of incubation and plant extract concentrations in their effects on the growth of mycelia. The two fungi renewed part of their activity after 168 hours of application of plant extracts.
\end{abstract}

Keywords: Antifungal activity, Pomegranate, Oak gall, Penicillium spp. , Aspergillus niger.

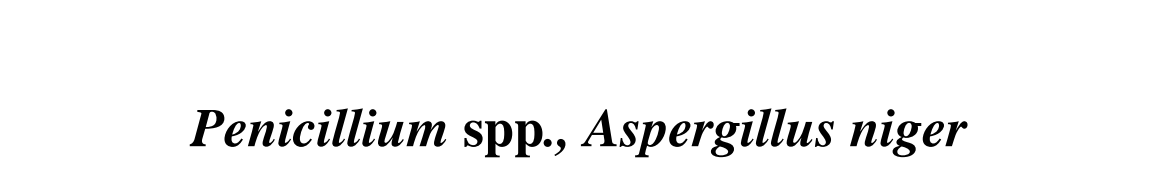

الماضص

لجريت عدة تجارب معملية بالتصميم العشوائي الكلل وأريع مكررات للكل معلملة في مختبرات قسم علوم

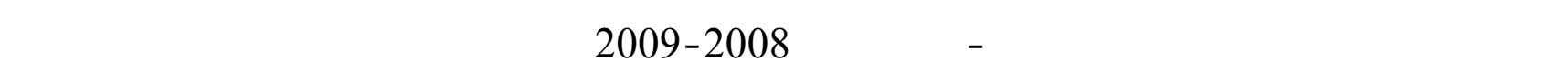
والكحولية لقثرة ثمار الرمان وثمار البلوط الفصي بترلكي -ز 0، 5، 10، 15 و20\% في في مكلفح فة فط ـري 


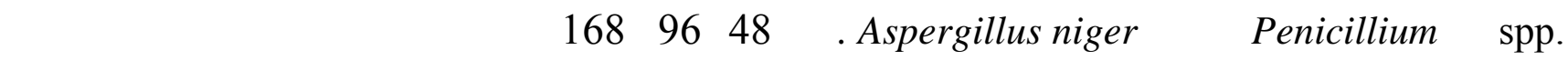

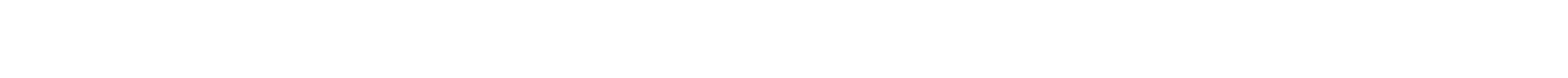

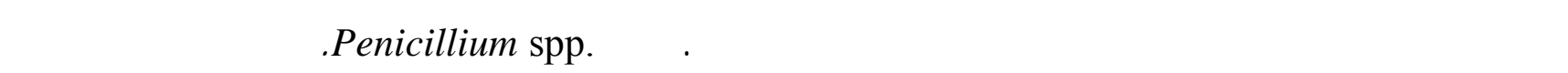

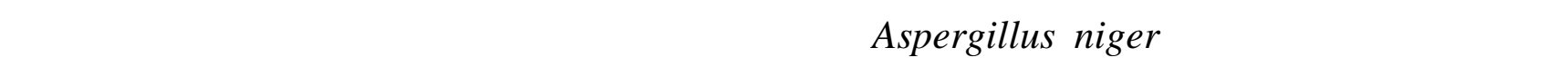
التأثير في نمو المليسيليوم للفطرين. كلا النطرين لستعادا نموهما جزئيا بمرور الوقت الهاملت الدالة: مضاد فطري، رملن، وثمار البلوط، فطر بنسيليوم، فطر لسبرجلس.

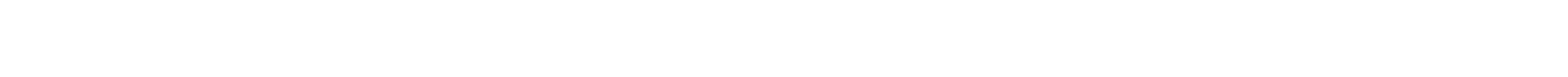
INTRODUCTION

The plant fungal diseases have traditionally been controlled by chemical fungicides. The development of resistant strains of pathogens against various chemical fungicides (Lin, 1981 ; Witte, 1998) and their harmful effects on soil biosphere and causing health hazards for humans and animals which found to pose carcinogenic risk due to their residual toxicity (Anonymous, 1998 ; Sarmamy, 2001) make the use of these chemicals limited. Because of these problems associated with the use of chemicals, researchers are trying to use environmentally safe alternative methods of fungal controls to reduce synthetic fungicides side effects. Plant extracts as natural products are widely used to control pests, since few last decades (Taiga et al., 2008; Joseph et al, 2008; Sarmamy et al., 2010 ; Basno, 2009). Plant extracts show antibacterial effects (Sarmamy and Al-Juboory, 2005) and antifungal activity against wide range of fungi (Aba Alkhail, 2005; Basm and Khalil, 2007; Sarmamy and Saleem, 2009). Pomegranate (Punica granatum) Punicaceae and oak galls (Quercus infectoria) Fagaceae are two well known medicinal plants grown in the region (Dohuk, Erbil and Suleymania). Galls are formed as a result of a pathologic swelling that infects the branches of normal oak by a female insect Cynipisgalle. The gall is formed when the insect drills the bud and puts its eggs in the wood (Hamawendi, 2006). The gall contains 50-70\% tannic acid, starch, resin, qurcetin, calcium salts and acids. The gall is used in folk medicine in the case of pyorrhea, gum bleeding, diarrhea, gastritis enteritis, clean skin burns, wounds and eczema (Al-Rawi and Chachravarty, 1988). It is also used in tannery, dying, and ink industry as well as being an important source for tannic acid.

The aim of the present study was to evaluate the antifungal activity of the tow plant extracts that widely distributed in the region such as oak gall and epicarp of pomegranate extracted with cold distilled water and ethanol against tow Penicillium spp. and Aspergillus niger.

\section{Preparation of extracts and culture}

\section{MATERIALS AND METHODS}

Epicarp of pomegranate fruits and oak galls were obtained from the local market. Plant segments (parts) were washed with tap water then by distilled water, dried by spreading them 
on a plastic sheet in the laboratory at the room temperature with occasional mixing to prevent fungal growth. Each plant parts were ground separately by electrical grinder and extracted by macerating $100 \mathrm{gm}$ of the powder of each plant material in $200 \mathrm{ml}$ of distilled water or $90 \%$ ethanol, and were put in an electric shaker for $24 \mathrm{hrs}$. Plant extracts were filtered by passing them through four folded layers of gauze and filtered by Buchnner apparatus and filter paper (Whatman No.4), then sterilized by passing them through bacterial filter (Seitz). Ethanol extract was concentrated by rotary vacuum evaporator at $45^{\circ} \mathrm{C}$. (Gull et al., 1988 ; Harborn, 1973). The extracts were kept in the refrigerator until use (Harborn, 1984). Concentrations of 0 , $5,10,15$ and $20 \%$ of the raw extracts were prepared and added to the sterilized (PDA) medium, mixed well then $20 \mathrm{ml}$ of the mixture (PDA medium + plant extract) were poured in each $9 \mathrm{~cm}$ sterilized Petri dishes. The medium without extract was served as control $0 \%$. Mycelial discs of fungi were prepared using a cork borer $(5 \mathrm{~mm}$ diameter) from the margin of 5 days old culture of the two tested fungi and placed at the centre of Petri dishes after solidification of PDA medium. Each treatment was replicated four times. Plates were incubated in an incubator at $25^{\circ}$ C. Fungal growth after 48, 96, and $168 \mathrm{hrs}$ was measured by taking the mean of the two diameters taken at right angles for each colony.

\section{Preparation of fungi}

Aspergillus niger was isolated from infected onion bulbs while Penicillium spp. was isolated from infected citrus fruits and pure cultures of the two isolated fungi were identified on the bases of morphological and microscopically characteristics according to the key of Barnett and Hunter (1972) and Bessy (1968).

\section{RESULTS AND DISCUSSION \\ Effects of pomegranate extract on controlling studied fungi Effects of aqueous extract of pomegranate:}

The results show (Table 1) that the aqueous extract of pomegranate affected significantly the growth of mycelium of Penicillium spp. and A. niger at all extract concentrations used (5, 10,15 and $20 \%$ ) by reducing the mycelial growth of Penicillium spp. and A. niger to 7 and 20.58-28.08 $\mathrm{mm}$ compared with control (53 and $60.67 \mathrm{~mm}$ ) for the tow fungi respectively. Time of incubation affected significantly the growth of mycelia. Figure 1 shows that the effect of aqueous extract on the growth of mycelia of Penicillium spp. The growth decreased with time and no differences between the extract concentrations in their effects were observed. The effect of aqueous extract on the growth of $A$. niger was more effective with time than Penicillium spp. (Figure 2). The mycelial growth was $7-12 \mathrm{~mm}$ after 68 hours of incubation and increased to $33.5 \mathrm{~mm}$ at $20 \%$ of the extract after 168 hours of incubation. It seems that $A$. niger recovered part of its activity after 168 hours of application of the plant extracts. The interaction between extract percentages and time is clear and the highest effects were $7 \mathrm{~mm}$ compared with $81 \mathrm{~mm}$ for control after 168 hours.

\section{Effects of ethanol extracts of pomegranate}

The different ethanol extract concentrations affected significantly the mycelial growth of the studied fungi (Table 1). In the case of Penicillium spp. all extract concentrations affected significantly and reduced mycelial growth (16.58-20.83 $\mathrm{mm})$ compared with control (53 $\mathrm{mm})$, 
and there is no significant difference between the different concentrations in their effects. In the case of $A$. niger the ethanol extracts affected significantly and reduced the mycelial growth to $29.33 \mathrm{~mm}$ at concentration of $20 \%$ compared with $60.67 \mathrm{~mm}$ for control.

Time of incubation affected on the growth of mycelia significantly. Figure 3 shows that all concentrations of ethanol extracts of pomegranate at the three times affected mycelial growth of Penicillium sp but the effects reduced after 168 hours. Figure 4 shows slight effects of all extract concentrations on the growth of $A$. niger except $20 \%$ and the fungus was recovered its activity after 96 and 168 hours of treatment. Data in table 1 show that Penicillium spp. was sensitive more than $A$. niger to pomegranate extracts.

\section{Effects of oak galls extract on controlling the studied fungi Effects of aqueous extract:}

Table 2 shows that the aqueous extract of oak galls at all concentrations affected significantly the growth of mycelia of Penicillium spp. and A. niger and reduced the mycelial growth of the two fungi to $15.33-23.83 \mathrm{~mm}$ and $31.08-48.25 \mathrm{~mm}$ respectively in comparison with 53 and $60.67 \mathrm{~mm}$ for the control of the two fungi respectively. Time of incubation also affected the growth of mycelia significantly and the effects of extracts reduced as the time increased. It seems that $A$. niger is resistant to plant aqueous extracts more than Penicillium spp. The mycelial growth was $34.5 \mathrm{~mm}$ after 48 hours of application and increased to 81.75 $\mathrm{mm}$ after 168 hours of application. Figure 5 shows significant interactions between time of incubation and extract concentrations, and the highest effect was at concentration of $20 \%$ and 48 hours of incubation $(60.5 \mathrm{~mm})$ compared with control and 168 hours of incubation $(70 \mathrm{~mm})$ for Penicillium spp. and $23 \mathrm{~mm}$ at concentration of $20 \%$ after 48 hours of incubation compared with $81.75 \mathrm{~mm}$ in control after 168 hours of incubation in case of $A$. niger (Figure 6).

\section{Effects of ethanol extract on controlling of studied fungi}

Table 2 shows that ethanol extract of oak galls at all concentrations affected significantly the growth of mycelia of Penicillium spp. and A. niger and reduced the mycelia growth of the two fungi to $14.0-26.25 \mathrm{~mm}$ and $31.5-48.25 \mathrm{~mm}$ in comparison with 60.5 and $65.75 \mathrm{~mm}$ for control of the two fungi respectively. Time of incubation after application of extracts affected significantly the growth of mycelia of the two fungi. After 48 hours of incubation the mycelial growth of Penicillium spp. was $14.8 \mathrm{~mm}$ increased to $40.8 \mathrm{~mm}$ after 168 hours and in the case of $A$. niger increased from $26.5 \mathrm{~mm}$ to $51 \mathrm{~mm}$ (Figures 7 and 8).

There were interactions between time of incubation and plant extract concentrations in their effects on the growth of mycelia for the two fungi. In the case of Penicillium spp. the highest effect was in concentration $20 \%$ after 48 hours of incubations $(7 \mathrm{~mm})$ compared with $70 \mathrm{~mm}$ for control and 168 hours of incubation. In the case of $A$. niger the highest effect was $23.5 \mathrm{~mm}$ compared with $81.75 \mathrm{~mm}$ in control after 168 hours of incubation.

Ethanol extract of Pomegranate and oak galls were more effective on controlling A. niger and Penicillium spp. than aqueous extract and caused significant reduction in mycelial growth for the two fungi (Tables 1 and 2). This may be due to the differences between the chemical components of the two plant extracts and most of the biological active chemicals are soluble in ethanol more than water such as volatile oils, tannin and glycosides and these components are 
physiologically active against fungi. oak galls containing tannins (Paaverurve and Raal, 2010), which have inhibitory effects on fungi (Vonshak et al., 2003), while pomegranate antifungal activity may be due to polyphenols and punicalagins (Seeram et al., 2006; Mertens et al., 2006; Plumb et al., 2002).

A. niger was more resistant against extracts of pomegranate and oak galls than Penicillium spp. This may be due to differences between the two fungi in their genetic constructions or may be due to the differences in the chemical and structural composition of the cell walls of the two fungi.

Table 1: Effects of aqueous and ethanol extracts of Pomegranate on the growth of Penicillium spp. and Aspergillus niger

\begin{tabular}{|c|c|c|c|c|c|}
\hline \multirow{2}{*}{\multicolumn{2}{|c|}{ Treatments }} & \multicolumn{4}{|c|}{ Pomegranate Extract (\%) } \\
\hline & & \multicolumn{2}{|c|}{ Aqueous } & \multicolumn{2}{|c|}{ Ethanol } \\
\hline \multirow{2}{*}{$\begin{array}{r}\mathrm{e} \\
\text { (hrs) }\end{array}$} & \multirow{2}{*}{$\begin{array}{r}\text { Con } \\
\mathrm{c} . \\
(\%)\end{array}$} & $\begin{array}{l}\text { Penicillium spp. } \\
\text { Mycelial Growth } \\
\text { (mm) }\end{array}$ & $\begin{array}{l}\text { Aspergillus niger } \\
\text { Mycelial Growth } \\
\text { (mm) }\end{array}$ & $\begin{array}{l}\text { Penicillium spp. } \\
\text { Mycelial Growth } \\
\text { (mm) }\end{array}$ & $\begin{array}{l}\text { Aspergillus niger } \\
\text { Mycelial Growth } \\
(\mathrm{mm})\end{array}$ \\
\hline & & Mean \pm S. E. & Mean \pm S.E & Mean \pm S. E. & mean \pm S. E. \\
\hline \multirow{6}{*}{48} & 0 & $28.5 \pm 1.56 \mathrm{c}$ & $34.5 \pm 0.65$ & $28.50 \pm 1.56$ & $34.5 \pm 0.65$ \\
\hline & 5 & $7 \pm 0.00 \mathrm{~d}$ & $12 \pm 0.41$ & $13.75 \pm 1.38$ & $33.0 \pm 0.71$ \\
\hline & 10 & $7 \pm 0.00 \mathrm{~d}$ & $10.5 \pm 0.29$ & $11.25 \pm 0.75$ & $31.75 \pm 1.18$ \\
\hline & 15 & $7 \pm 0.00 \mathrm{~d}$ & $7 \pm 0.00$ & $9.50 \pm 0.50$ & $27.50 \pm 1.04$ \\
\hline & 20 & $7 \pm 0.00 \mathrm{~d}$ & $7 \pm 0.00$ & $9.00 \pm 1.00$ & $17.50 \pm 1.04$ \\
\hline & $\mathrm{X}^{-}$ & $11.3 \pm 1.99 \mathrm{a}$ & $14.20 \pm 2.38 \mathrm{a}$ & $14.40 \pm 1.72 \mathrm{a}$ & $28.85 \pm 1.89 \mathrm{a}$ \\
\hline \multirow{6}{*}{96} & 0 & $60.5 \pm 0.50 \mathrm{~b}$ & $65.75 \pm 3.33$ & $60.5 \pm 0.50$ & $65.75 \pm 3.33$ \\
\hline & 5 & $7 \pm 0.00 \mathrm{~d}$ & $29.75 \pm 1.93$ & $18.75 \pm 0.75$ & $67.50 \pm 1.44$ \\
\hline & 10 & $7 \pm 0.00 \mathrm{~d}$ & $28.5 \pm 0.96$ & $18.00 \pm 0.71$ & $63.00 \pm 1.22$ \\
\hline & 15 & $7 \pm 0.00 \mathrm{~d}$ & $23 \pm 1.73$ & $16.25 \pm 0.75$ & $63.00 \pm 1.08$ \\
\hline & 20 & $7 \pm 0.00 \mathrm{~d}$ & $21.25 \pm 0.48$ & $15.5 \pm 1.33$ & $28.75 \pm 1.25$ \\
\hline & $\mathrm{X}^{-}$ & $17.7 \pm 4.88 \mathrm{a}$ & $33.65 \pm 3.81 b$ & $25.80 \pm 4.00 \mathrm{a}$ & $57.60 \pm 3.41 \mathrm{~b}$ \\
\hline \multirow{6}{*}{168} & 0 & $70 \pm 2.04 a$ & $81.75 \pm 1.18$ & $70.0 \pm 2.04$ & $81.75 \pm 1.18$ \\
\hline & 5 & $7 \pm 0.00 \mathrm{~d}$ & $42.5 \pm 1.04$ & $30.00 \pm 1.23$ & $77.75 \pm 0.85$ \\
\hline & 10 & $7 \pm 0.00 \mathrm{~d}$ & $38.5 \pm 0.65$ & $29.75 \pm 0.25$ & $74.00 \pm 1.69$ \\
\hline & 15 & $7 \pm 0.00 \mathrm{~d}$ & $35.25 \pm 1.65$ & $27.75 \pm 3.98$ & $75.25 \pm 1.03$ \\
\hline & 20 & $7 \pm 0.00 \mathrm{~d}$ & $33.5 \pm 0.96$ & $25.25 \pm 1.03$ & $41.75 \pm 0.86$ \\
\hline & $\mathrm{X}^{-}$ & $19.6 \pm \mathrm{c}$ & $46.30 \pm 4.12 b$ & $36.55 \pm 3.89 b$ & $69.50 \pm 3.30 c$ \\
\hline \multirow{6}{*}{$\mathrm{X}^{-}$} & 0 & $53 \pm 4.33 a$ & $60.67 \pm 6.02 a$ & $53.00 \pm 5.41 \mathrm{a}$ & $60.67 \pm 6.01 \mathrm{a}$ \\
\hline & 5 & $7 \pm 0.00 \mathrm{~b}$ & $28.08 \pm 3.84 \quad b$ & $20.83 \pm 2.14 b$ & $59.42 \pm 5.80 \mathrm{a}$ \\
\hline & 10 & $7 \pm 0.00 \mathrm{~b}$ & $25.83 \pm 3.51 b$ & $19.67 \pm 2.33 b$ & $56.25 \pm 5.45 a$ \\
\hline & 15 & $7 \pm 0.00 \mathrm{~b}$ & $21.75 \pm 3.56 b$ & $17.83 \pm 2.30 \mathrm{~b}$ & $54.25 \pm 5.84 a$ \\
\hline & 20 & $7 \pm 0.00 \mathrm{~b}$ & $20.58 \pm 3.29 b$ & $16.58 \pm 2.10 \mathrm{~b}$ & $29.33 \pm 3.04 b$ \\
\hline & $\mathrm{X}^{-}$ & $16.20 \pm 2.30$ & $31.38 \pm 2.64$ & $25.58 \pm 2.25$ & $51.98 \pm 2.75$ \\
\hline
\end{tabular}

* Means with different letters in a same column show significant differences as determined by Duncan's multiple range tests $(\alpha=0.01)$. 


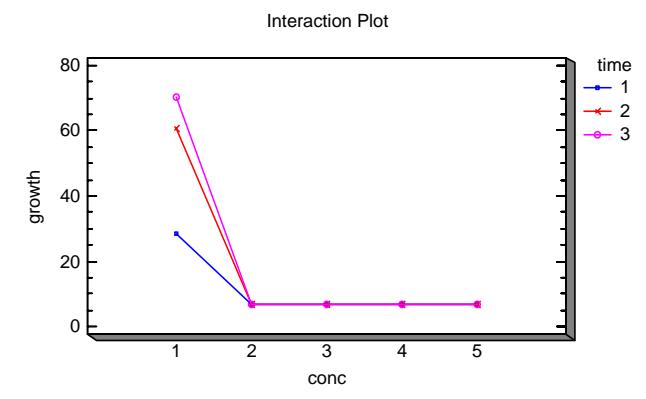

Fig. 1: Effect of interactions between Conc. of aqueous extracts of pomegranate and time of incubation on mycelial growth of Penicillium spp.

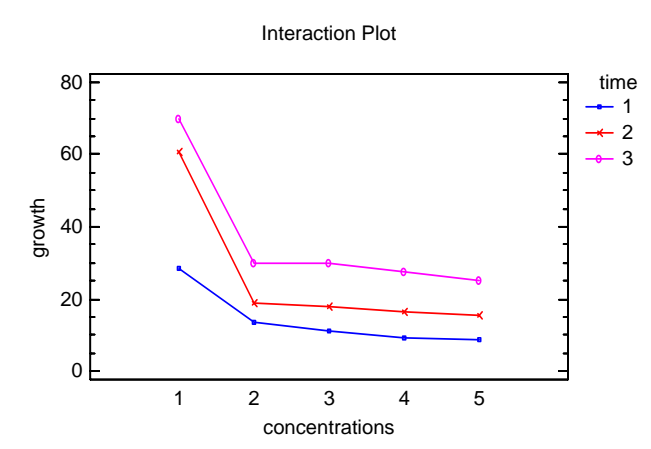

Fig. 3: Effect of interactions between conc. of ethanol extracts of pomegranate and time of incubation on mycelial growth of Penicillium spp.

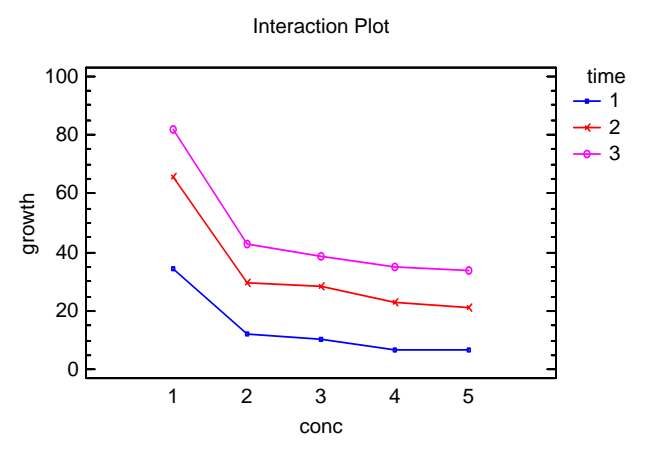

Fig. 2: Effect of interactions between conc. of aqueous extracts of pomegranate and time of incubation on mycelial growth of Aspergillus niger

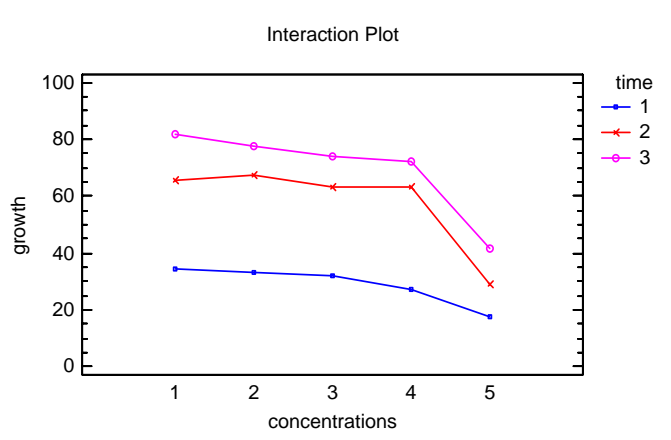

Fig. 4: Effect of interactions between conc. of ethanol extracts of pomegranate and time of incubation on mycelial growth of Aspergillus niger 
Table 2: Effects of aqueous and ethanol extracts of Oak galls on the growth of Penicillium spp. and Aspergillus niger.

\begin{tabular}{|c|c|c|c|c|c|}
\hline \multirow{2}{*}{\multicolumn{2}{|c|}{\begin{tabular}{|l|} 
\\
Treatments
\end{tabular}}} & \multicolumn{4}{|c|}{ Oak galls Extract (\%) } \\
\hline & & \multicolumn{2}{|c|}{ Aqueous } & \multicolumn{2}{|c|}{ Ethanol } \\
\hline \multirow[t]{2}{*}{$\begin{array}{l}\text { Time } \\
\text { (hours) }\end{array}$} & \multirow[t]{2}{*}{$\begin{array}{r}\text { Conc. } \\
(\%)\end{array}$} & $\begin{array}{l}\text { Penicillium spp. } \\
\text { Mycelial Growth } \\
\text { (mm) }\end{array}$ & $\begin{array}{c}\text { Aspergillus } \\
\text { niger } \\
\text { Mycelial Growth } \\
\text { (mm) }\end{array}$ & $\begin{array}{l}\text { Penicillium spp. } \\
\text { Mycelial Growth } \\
\text { (mm) }\end{array}$ & $\begin{array}{l}\text { Aspergillus niger } \\
\text { Mycelial Growth } \\
\text { (mm) }\end{array}$ \\
\hline & & mean \pm S.E. & mean \pm S.E & mean \pm S.E & mean \pm S.E \\
\hline \multirow{6}{*}{48} & 0 & $28.5 \pm 1.56$ & $34.5 \pm 0.65$ & $28.50 \pm 1.68$ & $34.5 \pm 0.65$ \\
\hline & 5 & $11.50 \pm 0.65$ & $34.25 \pm 1.49$ & $13.00 \pm 0.41$ & $34.25 \pm 1.49$ \\
\hline & 10 & $11.00 \pm 0.58$ & $26.75 \pm 1.38$ & $11.75 \pm 0.63$ & $26.75 \pm 1.38$ \\
\hline & 15 & $10.75 \pm 0.45$ & $24.0 \pm 1.47$ & $11.25 \pm 1.25$ & $24.00 \pm 1.47$ \\
\hline & 20 & $9.5 \pm 0.50$ & $23.5 \pm 1.45$ & $7.00 \pm 0.00$ & $23.50 \pm 1.49$ \\
\hline & $\mathrm{X}^{-}$ & $14.25 \pm 1.68 \mathrm{a}$ & $28.6 \pm 1.23 \mathrm{a}$ & $14.30 \pm 1.96 \mathrm{a}$ & $26.50 \pm 1.33 a$ \\
\hline \multirow{6}{*}{96} & 0 & $60.5 \pm 0.50$ & $65.75 \pm 3.33$ & $60.50 \pm 0.50$ & $65.75 \pm 3.33$ \\
\hline & 5 & $25.25 \pm 0.75$ & $48.25 \pm 1.44$ & $26.25 \pm 0.48$ & $48.25 \pm 1.44$ \\
\hline & 10 & $22.75 \pm 0.85$ & $38.5 \pm 0.95$ & $23.50 \pm 0.95$ & $38.50 \pm 0.96$ \\
\hline & 15 & $19.50 \pm 0.50$ & $34.75 \pm 1.25$ & $19.50 \pm 2.53$ & $34.75 \pm 1.25$ \\
\hline & 20 & $14.25 \pm 0.45$ & $31.5 \pm 0.95$ & $14.00 \pm 0.71$ & $31.50 \pm 0.95$ \\
\hline & $\mathrm{X}^{-}$ & $28.45 \pm 3.78 b$ & $43.75 \pm 2.92 b$ & $28.75 \pm 3.80 \mathrm{~b}$ & $40.70 \pm 3.31 b$ \\
\hline \multirow{6}{*}{168} & 0 & $70.0 \pm 2.04$ & $81.75 \pm 1.18$ & $70.0 \pm 2.04$ & $81.75 \pm 1.18$ \\
\hline & 5 & $34.75 \pm 0.85$ & $62.25 \pm 1.03$ & $47.50 \pm 2.50$ & $62.25 \pm 1.03$ \\
\hline & 10 & $32.00 \pm 1.23$ & $48.75 \pm 1.44$ & $34.75 \pm 1.89$ & $48.75 \pm 1.49$ \\
\hline & 15 & $28.50 \pm 1.45$ & $43.0 \pm 1.08$ & $28.50 \pm 1.55$ & $43.00 \pm 1.58$ \\
\hline & 20 & $22.25 \pm 1.31$ & $38.25 \pm 0.63$ & $21.25 \pm 1.25$ & $38.25 \pm 0.67$ \\
\hline & $\mathrm{X}^{-}$ & $37.50 \pm 3.89 \mathrm{~b}$ & $54.8 \pm 3.62 \mathrm{c}$ & $40.80 \pm 3.94 b$ & $51.00 \pm 4.12 \mathrm{c}$ \\
\hline \multirow{6}{*}{$\mathrm{X}^{-}$} & 0 & $53.0 \pm 4.33 \mathrm{a}$ & $60.67 \pm 6.02 \mathrm{a}$ & $53.00 \pm 5.08 \mathrm{c}$ & $60.67 \pm 6.01 \mathrm{a}$ \\
\hline & 5 & $23.83 \pm 2.90 b$ & $48.25 \pm 3.52 \mathrm{ab}$ & $28.92 \pm 4.35 b$ & $44.33 \pm 3.52 b$ \\
\hline & 10 & $21.92 \pm 2.64 \mathrm{~b}$ & $38.00 \pm 2.8 b c$ & $23.33 \pm 2.91 \mathrm{ab}$ & $35.17 \pm 2.17 \mathrm{bc}$ \\
\hline & 15 & $19.58 \pm 2.24 b$ & $33.92 \pm 2.44 b c$ & $20.42 \pm 2.57 \mathrm{ab}$ & $32.33 \pm 1.89 \mathrm{~cd}$ \\
\hline & 20 & $15.33 \pm 1.65 b$ & $31.08 \pm 1.9 \mathrm{c}$ & $14.08 \pm 1.81 \mathrm{a}$ & $24.50 \pm 1.47 \mathrm{~d}$ \\
\hline & $\mathrm{X}^{-}$ & $26.73 \pm 2.24$ & $42.38 \pm 2.11$ & $27.82 \pm 2.35$ & $39.4 \pm 2.22$ \\
\hline
\end{tabular}

*Means with different letters in a same column show significant differences as determined by Duncan's multiple range tests $(\alpha=0.01)$. 


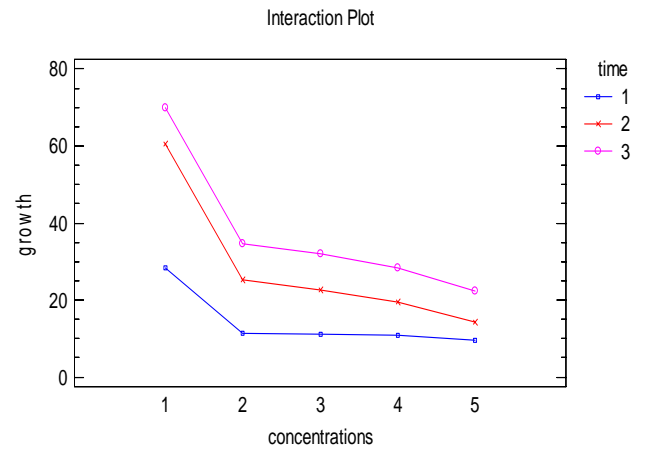

Fig. 5: Effect of interactions between conc. of aqueous extracts of oak galls and time of incubation on mycelial growth of Penicillium spp.

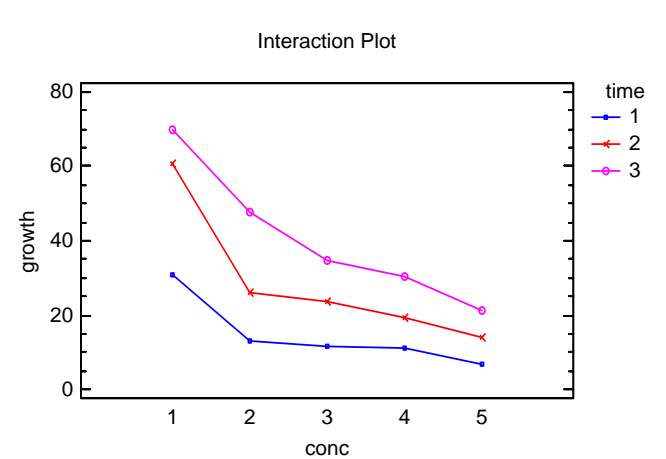

Fig. 7: Effects of interactions between conc. of ethanol extracts of oak galls and time of incubation on mycelium growth of Penicillium spp.

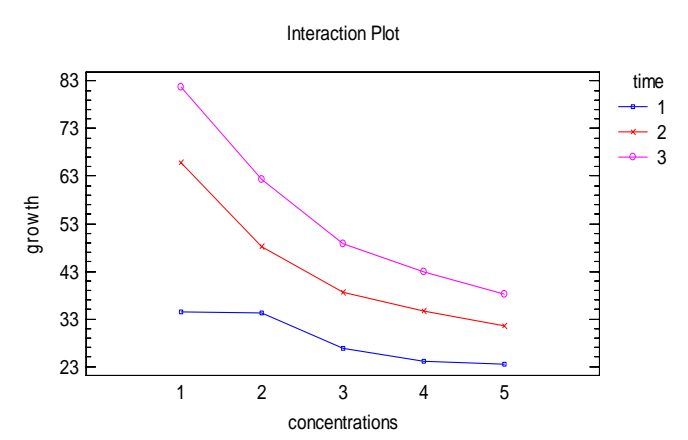

Fig. 6: Effect of interactions between conc. of ethanol extracts of oak galls and time of incubation on mycelial growth Aspergillus niger.

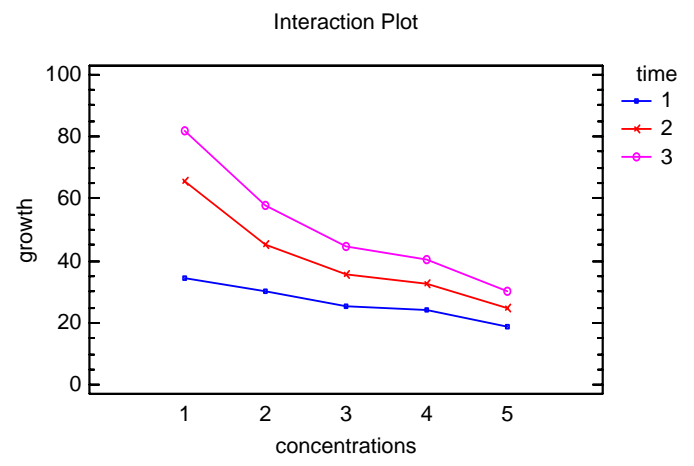

Fig.8: Effects of interactions between conc. of ethanol extracts of oak galls and time of incubation on mycelium growth of Aspergillus niger. 


\section{REFERENCES}

Aba Alkhail, A. A. (2005). Antifungal activity of some extracts against some plant pathogenic fungi. Pakistan J. Biol. Sci. 8(3), 413-417.

Al- Rawi, A. ; Chachravarti, H. L. (1988). Medicinal Plants of Iraq. 2nd edn. Al-Yakatha press. 109 p.

Anonymous, (1998). Pesticide incidents up for 1996/97 compared with previous year. International Pest Control. 40, $1 \mathrm{~B}$.

Barnett, H. L. ; Hunter, B. B. (1972). Illustrated Genera of Imperfect Fungi. 3rd edn. Burgess Publ. Com., Minneapolis, Minnesota, U.S.A, pp. 90-91.

Basm, F.D.; Khalil, A. (2007). The inhibitory effect of extracts from Jordanian medical plants against phytopathogenic fungi. Plant Path. J. 6(2), 191-194.

Basno, A. (2009). Effect of extract of Mondora myristica and Zingiber officinale on the growth of fungi in sweet potato juice. African J. Micro. Res. 3(9), 487-490.

Bessy, E. A. (1968). Morphology and Taxonomy of Fungi. Hanfer Publ. Com., New York and London. pp. 325-326.

Gull, H.; Chandhry, M. I.; Farooq, M.; Jan, R. (1988). Preliminary studies on antimicrobial activity of common wood of Pakistan and their extractive. Pakistan J. For. 38(3), 167173.

Hamawendi, N. J. K. (2006). Antifungal activities of extracts of some plants grown naturally in Kurdistan. Thesis, College of Education -University of Unbar, Unbar, Iraq.

Harborne, J. B. (1973). Phytochemical Methods. A Guide to Modern Techniques of Plant Analysis. Chapman and Hall (Distributed in the U.S.A. by Hasted Press).278 P.

Harborne, J. B. (1984). Phytochemical Methods. A Guide to Modern Techniques of Plant Analysis. Chapman and Hall.2nd edn. London, New York, 288 p.

Joseph, B.; Dar, M. A.; Kumar, V. (2008). Bio-efficacy of plant extracts to control Fusarium solani, f. spp. Melongenae incitant of Brinjal wilt. Global J. Biotech. and Bioch. 3(2), 56-59.

Lin, K.C. (1981). Resistance of ten tree species to sulfur dioxide. Bull. Taiwan For. Res. Inst.349, 14.

Mertens - Talcott, S.U.; Jilma-Stohlawetz, P.; Rios, J.; Hhingorani, L.; Derendorf, H. (2006). Absorption, metabolism and antioxidant effects of Pomegranate (Punica granatum L.) polyphenols after ingestion of a standardized extract in healthy human volunteers. $J$. Agric. food Chem. 54 (23), 8956-61.

Paaverurve, V. M. ; Raal, A. (2010). Total tannin content in distinct Quercus robur L. galls. J. Med. plant Res. 4 (8), 702-705.

Plumb, G. W.; De Pascual-Teresa, S. ; Santos-Buelga, C.; Rivas-Gonzalo J. C.; Williamson, G. (2002). Antioxidant properties of gallocatechin and prodelphinidins from Pomegranate peel. Redox Rep. 7(41), 41.

Sarmamy, A. O. I. (2001). Effect of some weed extracts on the growth of some pathogenous bacteria. Dissertation, Baghdad Univ., Baghdad, Iraq.

Sarmamy, A. O. I. ; Al-Juboory, B. A. (2005). Effect of rhubarb extracts on the growth of some pathogenic bacteria. Proc. 4th Int. Con. Biol. Sci. (Botany), 141-145, Tanta, Egypt. 
Sarmamy A. O.I. ; Saleem, Z. K. (2009). Impact of Ficus carica L. leave extracts on some pathogenic fungi.10th Arab Conf. P. Prot. Beirut, Lebanon.

Sarmamy, A. O. I.; Qarani, S. M. ; Khalil, A.K. (2010). In Vitro antimicrobial activity of Miswak extracts against some oral pathogenic isolates. Zanco, J. Med. Sci. 14(1), 7178.

Seeram, N. P.; Henning, SM.; Zhang, Y.; Liz, S. M. ; Heber, D. (2006). Pomegranate juice ellagitannin metabolites are present in human plasma and some persist in urine for up to 48 hours. J. Nutr.136 (10), 2481-5.

Taiga, A.; Suleiman, M. N.; Sule, W. ; Olufolaji, D. B. (2008). Comparative In Vitro inhibitory effects of cold extracts of some fungicidal plants on Fusarium oxysporum mycelium. Afric. J. Biotech. 7(18), 3306-3308.

Vonshak, A. ; Barazani, O. ; Sathiyamoothy, P.; Shalev, R.; Vardy, D. ; Golan-Goldhirsh, A. (2003). Screening of south Indian medical plants for antifungal activity against cutaneous pathogens. Phytother. Res. 17, 1123-1125.

Witte, W. (1998). Medical consequence of antibiotic use in agricultural. Science. 279, 11531154 . 